absolute necessity of such knowledge in literature, in science, and in commerce is already producing a most salutary reform.

The variety of types of secondary instruction demanded by the various needs and prospects of scholars requires a corresponding variety in the provision of schools. This cannot be settled by a rule-of-three method, as is done in the case of primary instruction. We cannot say that such and such an area being of such a size and of such a population requires so many secondary schools of such a capacity. Account must be taken in every place of the respective demands for respective types and grades of secondary education ; and existing provision must be considered.

It must not, however, be forgotten that a national system of education has its drawbacks as well as its advantages. The most fatal danger is the tendency of public instruction to suppress or absorb all other agencies, however long established, however excellent their work, and to substitute one uniform mechanical system, destructive alike to present life and future progress. In our country, where there are public schools of the highest repute carried on for the most part under ancient endowments, private schools of individuals and associations, and Universities entirely independent of the Government, there is reasonable hope that with proper care this peril may be escaped. But its existence should never be forgotten. Universal efficiency in all establishments that profess to educate any section of the people may properly be required ; but the variety, the individuality, and the independence of schools of every sort, primary and secondary, higher and lower, should be jealously guarded. Such attributes once lost can never be restored.

There still remains for our consideration the second division of Higher Education, viz., the applied or technological side. It is in this branch of Education that Great Britain is most behind the rest of the world; and the nation in its efforts to make up the lost ground fails to recognise the fact that real technical instruction (of whatever type) cannot possibly be assimilated by a student unless a proper foundation has been laid previously by a thorough grounding of elementary and secondary instruction. Our efforts at reform are abrupt and disconnected. A panic from time to time sets in as to our backwardness in some particular branch of commerce or industry There is a sudden rush to supply the need. Classes and schools spring up like mushrooms, which profess to give instruction in the lacking branch of applied science to scholars who have no elementary knowledge of the particular science, and whose general capacities have never been sufficiently developed. Students are invited to climb the higher rungs of the ladder of learning who have never trod the lower. But science cannot be taught to those who cannot read, nor commerce to those who cannot write. A few elementary lessons in shorthand and book-keeping will not fit the British people to compete with the commercial enterprise of Germany. Such sudden and random attempts to reform our system of technical education are time and money wasted. There are grades and types in technological instruction, and progress can only be slow. It is useless to accept in the higher branches a student who does not come with a solid foundation on which to build. In such institutions as the Polytechnics at Zurich and Charlottenburg we find the students exclusively drawn from those who have already completed the highest branches of general education ; in this country there is hardly a single institution where this could be said of more than a mere fraction of its students. The middle grades of technological instruction suffer from a similar defect. Boys are entered at technical institutions whose only previous instruction has been at elementary schools and evening classes; whose intellectual faculties have not been developed to the requisite point ; and who have to be retaught the elements to fit them for the higher instruction. In fact there is no scientific conception of what this kind of instruction is to accomplish, and of its proper and necessary basis of general education.

Yet this is just the division of higher education in which public authority finds a field for its operations practically unoccupied. There are no ancient institutions which there is risk of supplanting. The variety of the subject itself is such that there is little danger of sinking into a uniform and mechanical system. What is required is first a scientific, well-thought-out plan and then its prompt and effective execution. A proper provision of the various grades and types of technological instruction should be organised in every place. The aim of each institution should be clear; and the intellectual equipment essential for admission to each should be laid down and enforced. The principles of true economy, from the national point of view, must not be lost sight of. Provision can only be made (since it must be of the highest type to be of the slightest use) for those really qualified to profit by it to the point of benefiting the community. Evening classes with no standard for admission and no test of efficiency may be valuable from a social point of view as providing innocent occupation and amusement, but they are doing little to raise the technical capacity of the nation. So far from "developing a popular demand for higher instruction" they may be preventing its proper growth by perpetuating the popular misconception of what real technical instruction is, and of the sacrifices we must make if our people are to compete on equal terms with other nations in the commerce of the world. The progress made under such a system would at first be slow; the number of students would be few until improvements in our systems of primary and secondary instruction afforded more abundant material on which to work ; but our foundation would be on a rock, and every addition we were able to make would be permanent, and contribute to the final completion of the edifice.

It is the special function of the British Association to inculcate " a scientific view of things" in every department of life. There is nothing in which scientific conception is at the present moment more urgently required than in National Education ; and there is this peculiar difficulty in the problem, that any attempt to construct a national system inevitably arouses burning controversies, economical, religious, and political. It is only a society like this, with an established philosophical character, that can afford to reduce popular cries about education (which ignore what education really is, and perpetuate the absurdity that it consists in attending classes, passing examinations, and obtaining certificates) to their true proportions. If this Association could succeed in establishing in the minds of the people a scientific conception of a National Education. System, such as has already been evolved by most of the nations of Europe, the States of America, and our own Colonies, it would have rendered a service of inestimable value to the British nation.

\section{GEOLOGY AT THE BRITISH ASSOCIATION.}

$A \mathrm{~N}$ arduous week's work was carried out in the Section of Geology at Glasgow. There was a full list of papersin fact, too full for adequate discussion of all-ranging widely over the whole group of sciences combined under the name of geology. While stratigraphical papers were, as usual, in the ascendancy, petrology and palæontology were both strongly represented, mineralogy (with crystallography), of late years somewhat neglected in this Section, counted several contributions, and matters of physical and economic geology received attention in others. Many of the papers were admirably adapted for initiating discussion, and in some instances fulfilled this purpose, though, as generally happens with a heavy list, the discussions were somewhat unequally distributed. It might, perhaps, be said of many of the papers that they were instructive summaries of what was already known rather than new additions to our knowledge. The general arrangement was that the papers dealing with Scottish geology were taken as far as possible on Thursday and Friday, Saturday was given up to excursions, palæontological subjects occupied most of the Monday sitting, mineralogical papers were given precedence on Tuesday, and the concluding session on Wednesday served for the postponed or unclassified contributions. In the following outline of the proceedings of the Section we shall not have space to mention all the papers which were read, and must content ourselves with brief mention of those which seemed to us to be of chief interest.

After the president's address on Thursday, already printed in our columns, a paper on recent discoveries in Arran geology, by Mr. W. Gunn, of H.M. Geological Survey, read by Mr. Peach, gave a general summary of recent important advances in our knowledge of the island. Among its older rocks a series of dark schists and chert, unfossiliferous but probably of Arenig age, have been discovered; the Old Red Sandstone has been found to comprise two subdivisions, of which the upper is un conformable on the lower; the Carboniferous, including beds probably of Coal Measure age, are overlapped unconformably by the New Red rocks, the latter consisting of sandstones, conglomerates and marls which seem to be of Triassic age.

NO. I 666, voL. 64$]$ 
Fragments of Rhretic, Liassic and Cretaceous rocks which must once have covered the area have been recognised by their fossils in a large volcanic vent; this volcano was probably of Tertiary age. to which period are also assigned most of the igneous rocks, though six earlier periods of volcanic activity have been now recognised in this most interesting island.

Mr. G. Barrow followed with a suggestive paper on lateral variations of composition in zones of the Eastern Highland schists, which he ascribed to original variation in the sediments deposited in a delta. Mr. P. Macnair then gave his interpretation of the structure and probable succession of the schists of the Southern Highlands, which he considers to form an ascending sequence in the following order: Lower Argillaceous zone, Lower Arenaceous zone, Loch Tay Limestone, Garnetiferous schist, Upper Argillaceous zone and Upper Arenaceous zone.

The differentation of a rock-magma was well illustrated by Prof. J. Geikie and Dr. J. S. Flett in their description of the granite of Tulloch Burn, Ayrshire, which passes at its margins into intermediate and basic rocks.

The occurrence of a phosphatic layer at the base of the Inferior Oolite in Skye, lining a hollow of local erosion in the Upper Lias shales, was briefly described in a paper by Mr. H. B. Woodward.

On Friday the first paper was a lucid account by Sir Arch. Geikie of the re-discovery of a tree-trunk embedded in volcanic ash in Mull. This tree was described long ago by Macculloch, but occurs in a sea-cliff very difficult of access, and received no further notice until visited recently by Sir Arch. Geikie. The stump is about 5 feet in diameter and 5 feet high, and must have belonged to a tree originally at least $80 \mathrm{feet}$ high. It is of peculiar interest in showing that time-intervals of quiescence of considerable length occurred between separate volcanic outbursts.

Another notable contribution to Scottish volcanic geology was made by Mr. A. Harker in a paper on the sequence of the Tertiary igneous eruptions in Skye, read by Dr. Flett in the absence of the author. As the result of his detailed mapping of the volcanic rocks of Skye for the Geological Survey, Mr. Harker finds that he can recognise three successive phases of igneous activity - the volcanic, the plutonic, and the phase of minor intrusions. He further distinguishes two parallel series of events-the regional and the locai, the former of very wide extension, the latter connected with certain definite foci, one of which was situated in Central Skye.

The regional eruptive rocks are all of basic composition, but the local groups exhibit much greater diversity. During the plutonic phase the successive groups of intrusions at the Skye centre followed an order of increasing acidity ; but for the local groups of the succeeding phase of minor intrusions this order was reversed. Mr. Harker suggests that this sequence of Tertiary igneous eruptions may probably be taken as a type of the whole British area; and we may be sure that all student of these difficult rocks will await with impatience the publication of the detailed observations on which Mr. Harker's far-reaching generalisations are based.

Two papers by Messrs. A. McHenry and J. R. Kilroe, of the Irish branch of the Geological Survey, dealing with the older rocks of the north-west of Ireland and their bearing on Scottish geology, were next read. In the first the authors called attention to the close resemblance of the Old Red Sandstone of north west Ireland to the Torridon rocks of Sutherland both in composition and structural relationships, and suggested that the Torridon rocks were therefore really of Old Red age. This paper gave rise to an animated discussion, in which Profs. Sollas, Lapworth and Hull, Messrs. Peach, Barrow, Greenly, Goodchild, Caddell, Hinxman, Craig and the President took part. The consensus of opinion was that the suggested new reading of the Torridon succession could not be sustained; and one of the speakers aptly proposed that as the question had been wellthreshed out, an abstract of the discussion should be printed as a permanent record of the evidence for the age of the Scottish Torridonian.

Messrs. Kilroe and McHenry's second paper dealt with the relation of the Silurian and Ordovician rocks of north-west Ireland to the Great Metamorphic Series, their contention being that the latter consisted of metamorphosed Lower Silurian sediments and associated intrusions, over which the unmetamorphosed rocks were carried by overfolding and great dislocations in Llandovery times. In the next paper on the list, by
Mr. G. H. Kinahan, this view was controverted, and the earlier age of the metamorphic series upheld, these being compared with the Algonkian of North America.

Dr. Traquair then gave interesting lantern demonstrations on the geological distribution of the fishes of the Carboniferous rocks and of the Old Red Sandstone of Scotland. The study of the Carboniferous fish-faunas led to the conclusion that the rocks were divisible into two parts-Upper and Lower Carboniferous, with a great break at the base of the Millstone Grit, the Upper Carboniferous fauna being like that of England, and that of the Lower Carboniferous differing only where fresh-water or estuarine conditions displaced the marine forms. At a later session similar results were presented by Mr. R. Kidston in his description of fossil plants from Berwickshire.

In the concluding papers on Friday the Section was carried far afield by Miss C. A. Raisin in her account of the volcanic rocks of Perim Island, and by Dr. R. Logan Jack in his description of the conditions under which enormous supplies of artesian water are obtained in Queensland, where borings of the aggregate length of I85 miles have been made with incalculable advantage to the country, as the result of geological investigations in which Dr. Jack was a pioneer. The deepest of these borings attained the exceptional depth of 5045 feet.

On Monday, when precedence was given to palæontological papers, Mr. B. N. Peach came first with an admirable résumé of our knowledge of the Cambrian fossils of the North-West High. lands, in which stress was laid on the close agreement between the Scottish and North American fossil zones of this ancient period, betokening a shore-line connection between the continents, with a deep-water barrier to the southward, separating the north of Scotland from the mid-European and Welsh areas.

Prof. Sollas then exhibited and explained his machine for investigating fossil-remains. By Prof. Sollas's method the fossil is ground down slowly, and a series of parallel sections obtained from which it is easy to construct a model of the whole fossil. The great value of this machine as an instrument of research was demonstrated by a series of lantern slides and by wax models.

Mr. A. M. Bell gave an account of the plants and coleoptera from a Pleistocene deposit at Wolvercote, Oxfordshire; the plants indicated a more continental climate of the Thames valley during the period than at present, and a later date for the deposit than the Hoxne beds.

Papers on glacial geology were fewer than of slate years, and indeed, with the exception of the Report of the Erratic Blocks Committee, the only strictly glacial paper was that of Prof. P. F. Kendall and H. B. Muff on overfiow channels and other phenomena indicating glacier-dammed lakes in the Cheviots, in which region these observers have recently recognised similar phenomena to those which they had previously investigated in Yorkshire.

The application of geology to agriculture by the preparation of soil maps was the subject of a communication by Mr. J. R. Kilroe, who exhibited a specimen-map, on which the general character of the soil was indicated by a few colours selected from those of our usual geological maps, but intended to show the soil-characters only, without particular reference to the geological structure.

Tuesday was primarily the mineralogists' day, and the session was opened by Mr. J. G. Goodchild with a paper on the Scottish ores of copper in their geological relations, in which these ores were classed into two primary categories, those of the first being assigned to the uprise of thermal waters, and of the second to solutions passing downwards from higher to lower levels. The same author, in another communication, dealt with a revised list of Scottish minerals, and indicated its more salient points. Dr. W. Mackie followed with a series of three papers on the Trias of Elgin and Nairn; one describing the occurrence of barium sulphate and calcium fluoride as cementing substances in the Elgin area, believed by the author to have been directly deposited during the concentration of the waters of an inland lake; another recording covellite and mala. chite in a vein in the sandstone of Kingsteps, Nairn; and the third, on which there was an excellent discussion, on the pebbleband of the Elgin Trias, which was shown to be of wider extent than hitherto supposed and to mark a definite horizon at the base of the Trias, the overlying Cutties Hillock sandstones being really made up of Triassic sand-dunes, while in the pebble-bed many of the stones present characters showing them to have been wind-worn. At this point we may also 
mention a mineralogical paper by Dr. J. S. Flett, read at an earlier session, on crystals dredged from the Clyde near Helensburgh, which are believed to be pseudomorphs after celestine.

In a paper on the source of the alluvial gold of the Kildonan field, Sutherland, Mr. J. Malcolm Maclaren, as the result of a recent investigation, concludes that the gold has been derived from the white quartz veins of the local schists, whence it has been distributed into the glacial drift and finally concentrated mechanically in the present stream-courses. In a second paper Mr. Maclaren dealt with the influence of organic matter on the deposition of gold in veins, from personal observation on the reefs of the Sympic and Croydon goldfields of Queensiand and of the Ballarat field of Victoria, giving illustrations of the enrichment of the veins at the contact with carbonaceous or graphitic rocks, and suggesting the possibility of precipitation by carbonaceous matter, in accordance with the opinion once generally held, but latterly much discredited.

Mr. E. H. Cunningham Craig described the mode of occurrence of cairngorms, the search for which was formerly a profitable Scottish industry, but has now been practically abandoned. These idiomorphic quartz-crystals occur in the drusy central zones of veins of fine-grained granite traversing the normal coarser and less acid granites.

Prof. Joly's computations of the age of the earth from the amount of salt in the sea were incidentally criticised by $\mathrm{Mr}$. W. Ackroyd in a paper on the circulation of salt and its geological bearings. It was shown by Mr. Ackroyd that for the Millstone Grit and limestone districts of Yorkshire, as well as for a beit of the American coast some 200 miles broad, fully 99 per cent. of the salt carried by the rivers was cyclic sea-salt which had been atmospherically transported and carried down by rain, while Prof. Joly allows only Io per cent. as the proportion thus derived in our rivers. Reference was made to estimates by the author that during 1900-1901 the deposition of salt derived from the sea amounted to 172.3 lbs. per acre per year on the Pennine Hills at over 1000 feet above sea-level.

At the same session Mr. W. H. Wheeler discussed the sources of the warp in the Humber, urging that the material was brought down by the rivers flowing into the Iumber, and not by the inflowing tide from the waste of the Holderness coast as has been authoritatively stated. Two papers by Mr. J. Rhodes were also read, describing the discovery of phosphatic nodules and phosphate-bearing rock in the Upper Carboniferous Limestone series on the Yorkshire and Westmorland border, and of a silicified plant seam in the same locality.

There still remained a list of ten papers and reports to be taken at the final meeting on Wednesday, the majority being papers dealing with foreign geology. Dr. A. Smith Woodward sent an account of his recent investigations of the farnous bonebeds of Pikermi, Attica, where in re-working the old locality he obtained fragmentary evidence of a gigantic tortoise at least as large as the largest hitherto found in Europe, and in a new locality, at Achmet Aga in North Euboea, sixty miles distan from the former, he found a similar bone-bed, probably formed in like manner by torrential floods carrying down their débris into lakes.

Mr. H. J. L. Beadnell, of the Geological Survey of Egypt, also sent an account of the discovery of bone-beds of early Tertiary age in the Fayum depression, which have yielded many new mammalian and reptilian remains now being worked out by Dr. C. W. Andrews, of the British Museum, who visited the locality with Mr. Beadnell.

Prof. E. Hull, in continuance of his researches on submarine physiography, discussed the physical history of the Norwegian fjords. These he believes to be essentially river-valleys, of which the lower portions, probably once deep gorges traversing what is now the open sea-floor, are entirely filled with drift, and thus obliterated.

The origin of the gravel flats of Surrey and Berkshire was discussed by Mr. H. W. Monckton, who concludes that these deposits were river-gravels formed since the country last rose above the sea, during periods of repose in the process of elevation, which was differential in its effects.

As usual, much of the best work brought before the Section was embodied in the Reports of Committees of Research, for which, unfortunately, we have barely space for mention. The report of the Geological Photographs Committee, by Prof. W. W. Watts, and that on Erratic Blocks, by Prof. P. F. Kendall, showed the same substantial progress which these vigorous committees customarily present. The report on
Carboniferous Life-zones, by Dr. Wheelton Hind, and that on the Underground Waters of N.W. Yorkshire, by Captain A. R. Dwerryhouse, though hampered by unforeseen local difficulties in the latter case, also showed solid progress; while that on the Exploration of Irish Caves gave a preliminary account of the good results attained by the first year's working at Keish, co. Sligo; and that on the Structure of Crystals (drawn up by Mr. W. Barlow and Prof. H. A. Miers, assisted by Mr. G. F. Herbert Smith) forms an invaluable contribution to the history of crystallographic research.

As usual there were afternoon excursions during the meeting to places of geological interest within easy reach of Glasgow, besides the whole-day excursions to Girvan, Arran, Loch Lomond and The Trossachs on Saturday. The attendance at the sectional meetings throughout was quite up to the average of recent years, and general satisfaction was expressed with the character of the proceedings of Section $\mathrm{C}$ at Glasgow.

\section{ZOOLOGY OF THE TWENTIETH CENTUR $Y{ }^{1}$}

$W^{E}$ have stood in retrospect at the close of the nineteenth century and marvelled at what it brought forth. Here at the threshold of the twentieth century it is natural that we should wonder what it will unfold. Will the changes be as great and in what direction will advance chiefly be made? I am the more content to consider such questions for three reasons: first, because we can use history to formulate predictions; second, because the attempt may possibly influence to some slight degree the future development of zoology ; and third, because the attempt is tolerably safe since we shall none of us know all that the century will bring forth.

Comparing the beginning of the twentieth century with that of the nineteenth we find the most striking advances to have taken place in our morphological knowledge. The nineteenth may, indeed, be designated the morphological century. The demands of systematic zoology first made anatomical studies necessary. Later, comparison came to be accepted as the fundamental zoological method, and comparative anatomy, emancipated from its servitude to systematic zoology, became an independent science. Still later embryology arose, at first as a descriptive science and then as a comparative one. Out of embryology arose modern cytology, which in turn is creating a comparative histology. Partly as a result of studying embryology as a process has arisen the modern tendency toward comparative physiology. As a result of the general acceptance of the evolution doctrine the study of the geographical distribution of organisms and of adaptations has gained a new meaning. From the great matrix of "general biology" there have begun to crystallise out a number of well-defined subsciences.

Looking broadly at the progress made during the past century we see that zoology has become immensely more complex due to its developing in many lines, and that the new lines are largely interpolated between the old and serve to connect them. The descriptive inethod has developed into a higher type-the comparative; and of late years still a new method has been introduced for the study of processes-the experimental. The search for mechanisms and causes has been added to the search for the more evident phenomena. The zoologist is no longer content to collect data; he must interpret them

In view of the past history of our science what can we say of its probable future? We may be sure that zoology will develop in all these three directions: (I) The continued study of old subjects by old methods; (2) the introduction of new methods of studying old subjects; and (3) the development of new subjects.

I am not of those who would belittle the old subjects, even when pursued in the old way. There is only one class of zoologist that I would wish to blot out, and that is the class whose reckless naming of new "species" and "varieties" serves only to extend the work and the tables of the conscientious synonymy hunter. Other than this all classes will contribute to the advancement of the science. No doubt there are unlabled species and no doubt they must, as things are, be named. And no doubt genera and families must be "revised" and some groups split up and others lumped. So welcome to the old-fashioned systematist, though his day be short, and may

1 Address delivered before the Section of Zoology of the American Association for the Advancement of Science, at Denver, by Prof. C. B. Davenport, president of the Section.

NO. I666, vOL. 64] 